\title{
Urbanisme i comerç. Estratègies de localització d'Ikea a la Comunitat Valenciana
}

\author{
Gabino Ponce Herrero \\ Pablo Martí Ciriquián \\ Universitat d'Alacant \\ gabino.ponce@ua.es \\ pablo.marti@ua.es
}

Rebut: març de 2018

Acceptat: octubre de 2018

Publicat: juliol de 2019

\section{Resum}

Analitzem les estratègies de localització de l'empresa i les normes sectorials i urbanístiques que regulen l'activitat comercial a la Comunitat Valenciana. Valorem l'aplicació de la matriu d'Ansoff i les fortaleses de la matriu de Porter en el procés de geomàrqueting de l'empresa sobre territori valencià. Concloem que no són els interessos urbanístics ni socials de les ciutats valencianes els que determinen la localització previsible de dos establiments comercials de la firma Ikea. Ans al contrari, són les estratègies territorials d'aquesta empresa, fonamentades en la lògica de l'accessibilitat amb automòbil i del màxim benefici econòmic, les que determinen l'adaptació necessària dels plans sectorials, dels plans generals municipals i de la base socioeconòmica territorial.

Paraules clau: geomàrqueting; urbanisme comercial; urbanisme integral; matriu d'Ansoff; matriu de Porter

Resumen. Urbanismo y comercio. Estrategias de localización de Ikea en la Comunidad Valenciana

Analizamos las estrategias de localización de la empresa y las normas sectoriales y urbanísticas que regulan la actividad comercial en la Comunidad Valenciana. Valoramos la aplicación de la matriz de Ansoff y las fortalezas de la matriz de Porter en el proceso de geomarketing de la empresa sobre territorio valenciano. Concluimos que no son los intereses urbanísticos ni sociales de las ciudades valencianas los que determinan la localización previsible de dos establecimientos comerciales de la firma Ikea. Por el contrario, son las estrategias territoriales de esta empresa, fundamentadas en la lógica de la accesibilidad con automóvil y del máximo beneficio económico, las que determinan la adaptación necesaria de los planes sectoriales, de los planes generales municipales y de la base socioeconómica territorial.

Palabras clave: geomarketing; urbanismo comercial; urbanismo integral; matriz de Ansoff; matriz de Porter 
Résumé. Urbanisme et commerce. Stratégies pour localiser Ikea dans la Communauté Valencienne

Nous analysons les stratégies de localisation de l'entreprise et les normes sectorielles et urbanistiques régissant l'activité commerciale de la région autonome de Valencia (Comunidad Valenciana). La matrice d'Ansoff et les forces de la matrice de Porter ont été appliquées au géomarketing d'Ikea sur le territoire valencien. Nous concluons que ce ne sont pas les intérêts urbains ou sociaux des villes de la région qui déterminent l'emplacement à venir de deux établissements commerciaux de l'entreprise. Au contraire, ce sont les stratégies territoriales d'Ikea, suivant une logique d'accès automobile et de bénéfice économique maximum qui déterminent l'adaptation nécessaire des plans sectoriels, des plans municipaux généraux et de la base socio-économique territoriale.

Mots-clés: géomarketing; urbanisme commercial; urbanisme intégral; matrice d'Ansoff; matrice de Porter

\section{Abstract. Urbanism and business: Ikea location strategies in the region of Valencia}

This paper analyzes business location strategies and the industry and urban planning rules that regulate commercial activity in the region of Valencia. The application of Ansoff s Matrix and the strengths of Porter's Matrix are assessed in the process of business geomarketing in this region. The findings show that the foreseeable locations of two Ikea stores are not determined by urban planning or the social interests of towns and cities in the region of Valencia. On the contrary, the territorial strategies of this firm, based on the logic of vehicle accessibility and maximum profits, determine the necessary accommodation of industry plans, general municipal plans and regions' socioeconomic foundation.

Keywords: geomarketing; commercial urbanism; integral urbanism; Ansoff Matrix; Porter Matrix

\section{Sumari}

1. Urbanisme i funció comercial

2. Hipòtesi i objectius

3. Un marc legal flexible per als interessos de les empreses

4. Factors d'impuls als nous formats comercials a la Comunitat Valenciana

5. Les estratègies de geomàrqueting d'Ikea a la Comunitat Valenciana
6. El model econòmic aplicat al territori valencià

7. L'emplaçament en l'àrea metropolitana de València

8. Ikea com a subjecte passiu

9. Conclusions

Referències bibliogràfiques

\section{Urbanisme i funció comercial}

La dissolució dels confins urbans i els problemes de coordinació en el salt d'escala de la planificació urbana a l'ordenació del territori són temes substancials en la geografia actual (Nel.lo, 1996: 55; Muñoz, 2011; Bertran, 2011). En el sistema urbà valencià el trencament de la ciutat compacta en fragments aillats 
funcionalment especialitzats (Ponce, 2006) va unit a un procés d'expansió territorial de les àrees de mercat, que va de la mobilitat quotidiana (Salom i Casado, 2007) a impulsos de l'equipament privat i particular (automòbil), com també a l'augment i la millora de les infraestructures de transport (Salom i Albertos, 2014). La dispersió de funcions, més enllà dels confins municipals, i els nous reptes per a l'ordenació coordinada són temes tractats per diferents autors (Boira, 2000; Ponce, 2005; Espinosa, 2007; Burriel, 2009a, 2009b; Salom, 2011; Ponce, 2013).

Resulta substancial la suburbanització de la funció comercial, que, amb els nous formats, introdueix nous criteris d'ordenació territorial (Boira, 2000; Vahí i Feria, 2007). L'èxit de les estratègies empresarials es correspon amb l'agilitat del sector per anticipar-se a les noves demandes, hàbilment detectades molt abans que arriben a plasmar-se en els plans d'ordenació urbana, un procés amb més control social, però més lent i complex. Triomfa la lògica del ciutadà consumidor davant la lògica social i el model de convivència integrat.

És un tema d'una gran actualitat en els debats urbans a tot Europa (Desse, 2010) que indica la necessitat de potenciar el paper de les institucions públiques davant un vigorós sector comercial impulsat per empreses internacionals i que ha pogut ser encarrilat en algunes ciutats europees cap a un model més sostenible, en vincular, mitjançant acords, els nous equipaments comercials amb el transport públic (Dugot i Pouzenc, 2010).

És una qüestió que ha assolit un gran interès en la geografia comercial, centrada avui en l'estudi de les relacions entre grans empreses de distribució comercial i noves promocions immobiliàries a partir de l'anàlisi de les estratègies de difusió espacial (Desse, 2009; Desse et al., 2016).

\section{Hipòtesi i objectius}

Proposem, com a paradigma, l'estudi de cas de la localització dels establiments de la firma Ikea a la Comunitat Valenciana, perquè reuneix tot un conjunt d'estratègies coordinades encaminades a aconseguir avantatjoses localitzacions en entorns ja evolucionats cap a formes suburbanes de ciutat i de comportaments ${ }^{1}$. Les estratègies d'Ikea han sigut analitzades per a uns altres casos (Roger et al., 1998; Burt et al., 2011; Jonsson i Foss, 2011), no tant per a Espanya. Més enllà de la mateixa empresa (Torekull, 2008), les anàlisis se centren en el seu model de negoci (Cerdá, 2014; Aguirre, 2014).

Es manté la hipòtesi que les grans companyies comercials, en aquest cas exemplificada en el cas d'Ikea a la Comunitat Valenciana, desenvolupen unes estratègies molt eficaces de penetració en els mercats territorials ja madurs, amb un gran impacte urbanístic, que es concreten en la creació de nodes comercials

1. Es tracta, tanmateix, d'un model comercial afectat per la creixent competència de les noves plataformes de compra digital i per la recuperació del comerç de proximitat, com evidencien les crisis de Walmart als Estats Units i de Carrefour a Europa. 
suburbans nous i "propis» en què s'exerceix un «dret d'admissió» sobre uns altres comerços complementaris.

Com a objectiu fonamental proposem comprovar el compliment de les estratègies teòriques de penetració en el mercat valencià d'una empresa amb un nou format de "centre comercial de fabricant» i la pressió sobre les figures de planejament urbanístic. Són objectius secundaris analitzar el grau de maduresa de la demanda de mercat valencià i comprovar la capacitat dels sistemes d'informació geogràfica per als estudis de geomàrqueting.

El marc conceptual i l'estat actual es basen en l'anàlisi de les fonts primàries relacionades en la bibliografia. Les dades quantitatives procedeixen de l'INE, de les figures de planejament i de diverses associacions empresarials. Fem una anàlisi de geodemanda multivariable (població vinculada, tipologia d'habitatges, automòbils, turisme residencial i perspectives de sòl urbanitzable) per a conèixer l'evolució recent del comerç minorista i de les grans superfícies. Hi ha també un estudi de geomàrqueting i geocompetència a partir del model Maximize Overall Customer Coverage (Bosque i Moreno, 2014), desenvolupat amb l'aplicació ArcGIS 10.1, que permet trobar localitzacions òptimes a partir de l'anàlisi espacial (Alcaide et al., 2012), però eixes localitzacions teòriques es veuen afectades per uns altres criteris imponderables. Per això, els sistemes d'informació geogràfica s'han complementat amb models qualitatius, com ara la matriu de vector de creixement (Ansoff, 1976), basada en l'obertura de nous mercats d'una firma mitjançant estratègies de distribució i localització per a captar nous clients i clients de la competència. Més ajustada sembla l'anàlisi de les cinc forces d'assentament que defineix la matriu de Porter (Porter, 1989), especialment perquè recull l'estratègia d'influir en els responsables polítics per a fer front amb avantatge a la rivalitat davant d'uns altres possibles competidors.

\section{Un marc legal flexible per als interessos de les empreses}

Per la importància que té en l'urbanisme, l'activitat comercial ha sigut regulada a la Comunitat Valenciana mitjançant lleis i decrets des de 1986. Però el Pla d'acció territorial sectorial del comerç (PATSECOVA) per al conjunt de la Comunitat Valenciana proposat l'any 2004 encara no s'ha aprovat. Per aquest motiu hi ha un cert nivell d'ambigüitat en la interpretació de les normes, cosa que ha portat a cometre excessos a l'hora d'aplicar-les (Boira, 2000; Hermosilla, 2000; Ponce, 2014). En aquest sentit, apunta el «paquet de les Mesures urgents d'impuls a la implantació d'actuacions territorials estratègiques» de 2011 per a desenvolupar actuacions territorials estratègiques (ATE) per damunt de l'ordenació existent. També la Llei del comerç de 2011, en l'article 31.3 de la qual s'hi explicita que «En cap cas, el Pla d'Acció Territorial Sectorial del Comerç de la Comunitat Valenciana prendrà en consideració l'impacte de la implantació de nous establiments comercials sobre l'oferta comercial ja existent», i al punt 4 de la qual es diu que «El Pla d'Acció Territorial Sectorial del Comerç de la Comunitat Valenciana podrà modificar, de forma directa, les previsions dels plans generals vigents, pel que fa a la planificació del sòl comercial». A més, 
l'article 33, que regula els establiments comercials d'alt impacte, especifica que la implantació «no estarà subjecta al règim d'autorització comercial» ni al procediment o a la resolució, cosa que hem indicat.

Els municipis han aprofitat aquestes possibilitats, i unes altres que són derivades del marc legal urbanístic, per a donar cobertura legal a les modificacions realitzades en els plans generals de les ciutats valencianes que han optat a ser seu d'Ikea (de manera pública i també de forma més secreta) ${ }^{2}$. A Alacant, però, la qüestió s'ha intentat desenvolupar mitjançant una ATE, figura que pot ser impulsada a propostes de tercers (empresaris), pel municipi mateix i des del Govern regional, com ha succeït, encara que sense acord entre els tres nivells a causa de les conjuntures polítiques.

\section{Factors d'impuls als nous formats comercials a la Comunitat Valenciana}

Des de la publicació d'El corazón de la ciudad (Rogers et al., 1955), hi ha hagut molts treballs que expliciten com els nous centres comercials han sostret la funció de node de socialització que abans tresorejaven els centres urbans. L'èxit d'aquests nous centres comercials respon a la suma de criteris inherents: d'una banda, a la nova demanda dels ciutadans consumidors i, de l'altra, a la resposta àgil de les empreses del ram. A continuació s'analitzen sintèticament aquests dos criteris per a conèixer si es troben, $\mathrm{i}$ en quina mesura, entre les causes decisives de la implantació d'Ikea a la Comunitat Valenciana.

\subsection{Factors vinculats amb la demanda}

L'augment de les rendes és un factor decisiu (Cerdá, 2007). Així, la menor renda de la Comunitat Valenciana respecte de la mitjana estatal podria explicar el retard de l'obertura dels Ikea de València (any 2014) i Alacant (prevista per al 2015, però encara sense construir). No obstant això, hi ha uns altres factors igualment importants que caldria buscar en la diferent escala metropolitana de València i urbana d'Alacant. Entre aquests hi trobem les reticències polítiques a Alacant (la «cinquena fortalesa» de la matriu de Porter, que s'analitza més endavant) i la influència positiva d'un mercat suburbà més madur i dens a València.

2. Diari Las Provincias de 7 d'octubre de 2008 (traducció): «Alfafar Parc inclou en el seu projecte un Ikea que la firma no descarta i que Indústria qüestiona»; "La nostra feblesa és que no podem revelar els acords que tenim» (amb Ikea). Recuperat el 12 de setembre de 2014, de <http://www.lasprovincias.es/valencia/20081107/economia/alfafar-parc-incluyeproyecto-20081107.html>.

Coto Consulting, 1 de febrer de 2009 (traducció): «L'Ajuntament d'Alfafar lluita abrivadament, des de l'ombra, per aconseguir que la primera tenda d'Ikea s'instal.le en el municipi». Recuperat el 14 de setembre de 2014, de <http://www.cotoconsulting.com/ alfafar-busca-apoyos-de-ayuntamientos-y-empresas-para-que-ikea-abra-en-lhorta-sud/> .

Diari Información de 7 de juny de 2011 (traducció): "Sant Joan i Mutxamel van licitar per Ikea, segons les escoltes». Recuperat el 12 de setembre de 2014, de <http://www. diarioinformacion.com/portada-alicante/2011/06/07/sant-joan-mutxamel-pujaron-ikeaescuchas/1135853.html>. 
Taula 1. Evolució de la ràtio de turismes per habitant (per províncies i a Espanya)

\begin{tabular}{lccccc}
\hline & Alacant & Castelló & València & $\begin{array}{c}\text { Comunitat } \\
\text { Valenciana }\end{array}$ & Espanya \\
\hline 2016 & 0,51 & 0,51 & 0,47 & 0,49 & 0,49 \\
2011 & 0,47 & 0,47 & 0,47 & 0,47 & 0,47 \\
2005 & 0,49 & 0,47 & 0,47 & 0,48 & 0,46 \\
2000 & 0,47 & 0,44 & 0,44 & 0,45 & 0,43 \\
1996 & 0,38 & 0,37 & 0,37 & 0,37 & 0,36 \\
\hline
\end{tabular}

Font: INE, Ministeri de l'Interior. Elaboració pròpia.

L'augment de vehicles, que ompli els centres comercials urbans, i l'escassesa d'aparcaments afecten l'atractiu del comerç tradicional (López, 2002). Per contra, la facilitat d'accés i d'aparcament sustenta l'èxit del comerç suburbà (Jones i Simmons, 1990). La disponibilitat d'automòbils en les llars permet fer compres més copioses i, per això, espaiades en el temps, de manera que deixen de ser necessitat urgent i poden planificar-se com a eixides familiars multipropòsit vinculades amb l'oci (Cliquet et al., 2006).

La ràtio de turismes a la Comunitat Valenciana (taula 1) és un aspecte favorable, però molt genèric, que estaria afavorint la transformació general dels estils de vida i, amb això, dels hàbits de compra i relació social. En el cas de la Comunitat Valenciana, aquests nous comportaments s'haurien vist reforçats per l'arribada d'immigrants de caràcter residencial (més significatiu en el cas d'Alacant), per la major incorporació de la dona al mercat laboral (predomini industrial i terciari), per la reducció de la mitjana de persones en cada llar, per la dispersió d'aquestes per l'espai suburbà (especialment les llars amb major renda) o per l'augment consegüent del nombre d'habitatges i la dispersió per l'espai suburbà. Són aspectes que, en general, també semblen sobreeixir en el cas de València (taula 2).

També hi influiria l'augment de la despesa en els formats minoristes (Gutiérrez, 2014), molt afectats per la crisi, tant en el conjunt de l'Estat com

Taula 2. Variables socioeconòmiques de rellevància comparades (per províncies)

\begin{tabular}{|c|c|c|c|c|c|}
\hline & \multicolumn{3}{|c|}{ Comunitat } & \multirow[b]{2}{*}{ Castelló } & \multirow[b]{2}{*}{ València } \\
\hline & Espanya & Valenciana & Alacant & & \\
\hline Percentatge de dones actives 2016 & 53,4 & 54,6 & 53,7 & 52,9 & 55,7 \\
\hline Percentatge d'estrangers, residencial ${ }^{\star} 2017$ & 16,0 & 27,1 & 43,6 & 7,5 & 11,2 \\
\hline Habitatges per habitant 2011 & 0,54 & 0,63 & 0,69 & 0,71 & 0,57 \\
\hline Percentatge de llars d'una o dues persones & 53,3 & 54,9 & 56,6 & 53,8 & 54,0 \\
\hline Percentatge de teixit urbà discontinu 2006 & 33,31 & 36,71 & 49,39 & 22,92 & 27,5 \\
\hline Percentatge d'habitatge unifamiliar aïllat 2009 & 36,61 & 37,46 & 48,11 & 26,22 & 31,08 \\
\hline Habitatges/hectàrea 2011 & 22,44 & 27,54 & 26,26 & 20,53 & 32,1 \\
\hline
\end{tabular}

*Aproximació segons l'origen en països més desenvolupats que Espanya.

Font: INE, Ministeri de Foment, Sistema d'informació urbana. CORINE 2006, SIOSE 2009. Elaboració pròpia. 
Figura 1. Evolució comparada de la taxa de creixement interanual de la facturació del comerç minorista a Espanya i a la Comunitat Valenciana

$\% \quad$ Evolució comparada (TCl \%) facturació comerç minorista

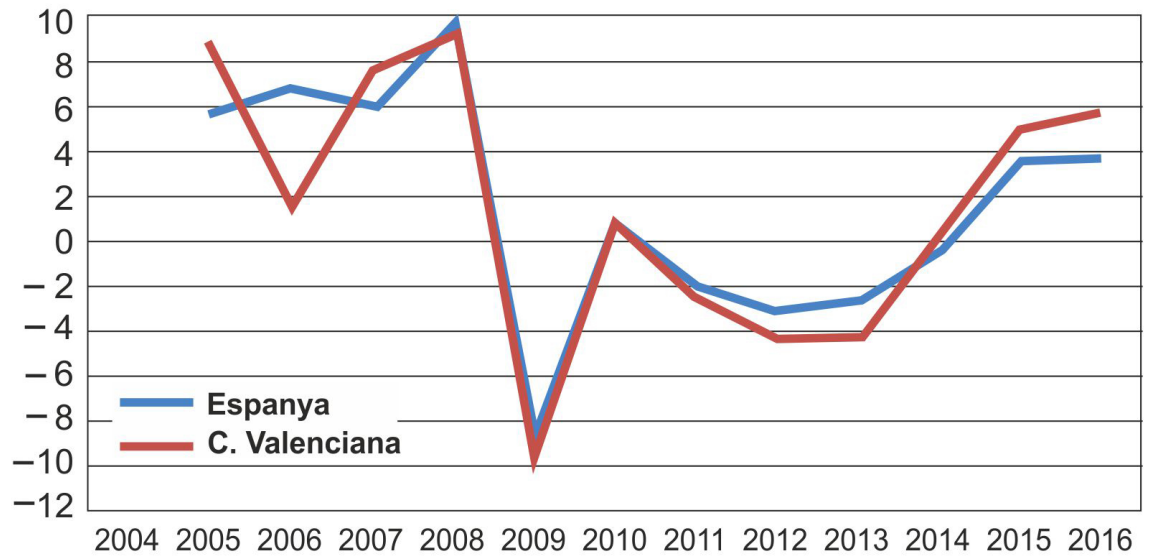

Font: PATECO. Elaboració pròpia.

a la Comunitat Valenciana (figura 1), però que presenta millors indicadors de recuperació en el comerç minorista valencià (taula 3 ).

A partir de les dades comentades podríem considerar que, en efecte, el sector comercial a la Comunitat Valenciana presenta uns índexs de maduresa, en el conjunt territorial, ajustats a les exigències per a la localització de centres comercials suburbans. De l'anàlisi de les variables combinades en l'Atlas estadistico de las áreas urbanas de España (figura 2) s'infereix que, a més, en la decisió d'establir els magatzems d'Ikea, han sigut decisives les fortes concentracions de població, en tots els casos de més de 500.000 habitants (Ministeri de Foment, 2000, 2006 i 2017).

Taula 3. Evolució comparada de la competitivitat del comerç minorista

\begin{tabular}{cccccc}
\hline & \multicolumn{2}{c}{ Ràtio vendes/local $^{*}$} & & \multicolumn{2}{c}{ Ràtio vendes/treballadors $^{* *}$} \\
\cline { 2 - 3 } \cline { 5 - 6 } Any & Espanya & Comunitat Valenciana & & Espanya & Comunitat Valenciana \\
\hline 2011 & $0,00 \%$ & $-1,60 \%$ & & $-2,20 \%$ & $-2,70 \%$ \\
2012 & $-2,20 \%$ & $-3,40 \%$ & & $-2,40 \%$ & $-3,30 \%$ \\
2013 & $-1,30 \%$ & $-2,40 \%$ & & $-0,70 \%$ & $-2,20 \%$ \\
2014 & $1,10 \%$ & $1,90 \%$ & & $-0,20 \%$ & $-0,20 \%$ \\
2015 & $1,90 \%$ & $7,40 \%$ & & $-0,20 \%$ & $4,70 \%$ \\
2016 & $3,40 \%$ & $5,30 \%$ & & $-0,20 \%$ & $0,70 \%$ \\
\hline
\end{tabular}

* Variació percentual de la quantitat de vendes en euros per local.

** Variació percentual del nombre de treballadors amb relació a la quantitat de vendes.

Font: Informe PATECO. Elaboració pròpia. 
Figura 2. Grans àrees urbanes d'Espanya i obertures d'establiments Ikea (marcats amb una estrella). El 1996 començava l'expansió d'lkea per Espanya, que mostrava una correlació clara amb les àrees urbanes majors de 500.000 habitants

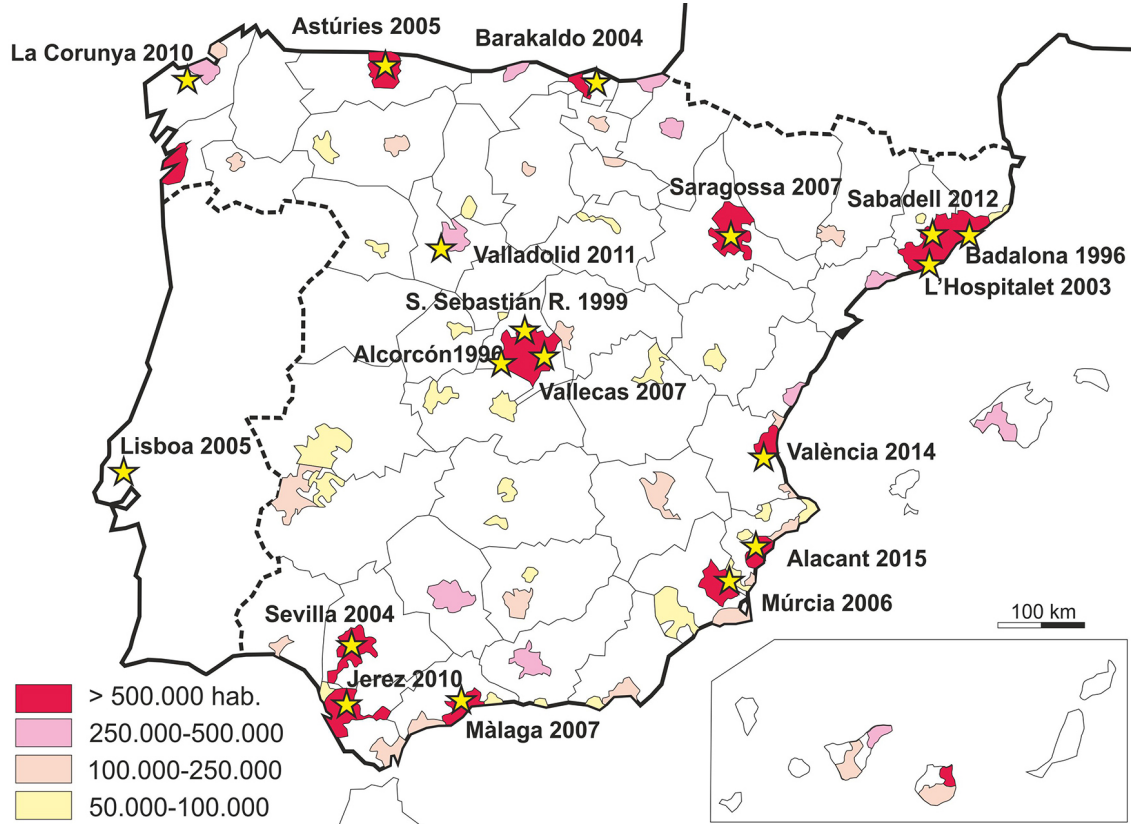

Font: Atlas estadístico de las áreas urbanas de España, 2006. Elaboració pròpia.

En la taula 4 es comparen les variables socioeconòmiques que mostren el dinamisme de les àrees urbanes afectades (inclou Múrcia, ja que la seua zona d'influència s'expandeix per la meitat meridional de la província d'Alacant). En tots els casos, a més de població vinculada a menys de 20 minuts, destaca la quantitat de sòl urbanitzable, d'àrees de desenvolupament, d'habitatges previstos, d'habitatges unifamiliars aïllats i de teixit urbà discontinu.

\subsection{Factors vinculats amb l'oferta}

En els espais urbans centrals se succeeixen els tancaments dels petits comerços tradicionals. Alhora, els petits empresaris, segons les seues possibilitats, migren als centres comercials minoristes per a beneficiar-se del comportament comparatiu i multipropòsit dels clients (Cruz, 2002). La crisi econòmica i l'aparent eixida d'aquesta han impulsat canvis a la Comunitat Valenciana (figura 3): descendeixen els locals comercials (un 15\%) i, amb aquests, els especialitzats en articles de la llar, al mateix temps que augmenta l'afluència als centres comercials (un 15\%). En el mateix sentit apunta l'evolució recent de l'índex de vendes del comerç minorista, segons formats: l'any 2016, les vendes de 
Taula 4. Variables comparades de dinamisme socioeconòmic. Àrees urbanes

\begin{tabular}{lrrr}
\hline \multicolumn{1}{c}{ Variable } & $\begin{array}{c}\text { Àrea metropolitana } \\
\text { de València } \\
45 \text { municipis }\end{array}$ & $\begin{array}{c}\text { Àrea urbana } \\
\text { d'Alacant-Elx } \\
6 \text { municipis }\end{array}$ & $\begin{array}{c}\text { Àrea urbana } \\
\text { de Múrcia } \\
10 \text { municipis }\end{array}$ \\
\hline Habitants 2016 & 1.546 .128 & 693.592 & 648.816 \\
Densitat habitants/km² & 2.459 & 1.015 & 526 \\
Percentatge de llars d'una o dues persones & 55,1 & 54,3 & 46,3 \\
Percentatge de sòl urbà consolidat & 12,98 & 12,15 & 7,33 \\
Percentatge de sòl urbà no consolidat & 1,14 & 0,97 & 0,84 \\
Percentatge de sòl d'àrees de desenvolupament & 4,66 & 6,94 & 13,62 \\
Percentatge de sòl urbanitzable delimitat & 3,52 & 5,97 & 12,77 \\
Percentatge de sòl urbanitzable no delimitat & 4,53 & 1,62 & 19,35 \\
Habitatges previstos & $27.292^{*}$ & $114.604^{*}$ & $264.451^{*}$ \\
Densitat habitatges/hab. & 33,52 & 27,02 & 20,14 \\
Percentatge de teixit urbà continu 2006 & 41,7 & 26,8 & 35,55 \\
Percentatge de teixit urbà discontinu 2006 & 16,11 & 42,87 & 23,26 \\
Percentatge d'habitatge unifamiliar aïllat & 21,17 & 42,28 & 32,98 \\
Percentatge d'habitatge secundari & 7,8 & 20,9 & 4,5 \\
Percentatge de població vinculada $<$ 20 minuts & 56,6 & 65,8 & 68,7 \\
Superfície grans magatzems m²/hab. & 0,46 & 0,47 & 0,51 \\
\hline
\end{tabular}

${ }^{*}$ Anys 2011, 2014 i 2013, respectivament.

Font: INE, Ministeri de Foment. Atlas digital de las áreas urbanas de España. Elaboració pròpia.

Figura 3. Comunitat Valenciana. Evolució del comerç minorista i de l'especialitzat en articles per a la llar, comparat amb l'afluència a centres comercials

\section{Locals}

Milions persones

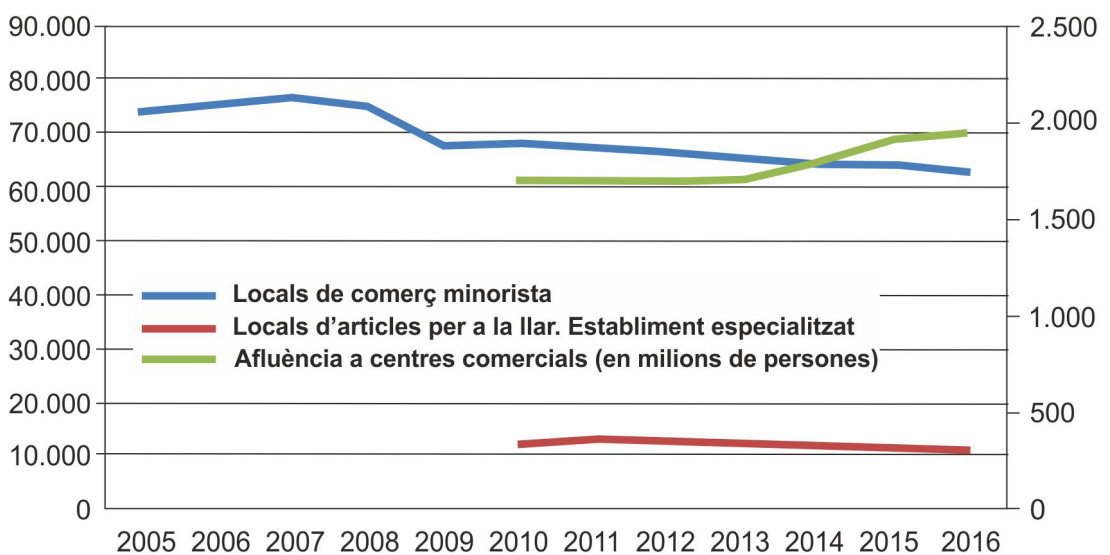

Font: INE, DIRCE, PATECO. Elaboració pròpia. 
Taula 5. Relació entre centres comercials i habitants (per províncies), any 2016

\begin{tabular}{lccrrr}
\hline & Espanya & Comunitat Valenciana & Alacant & València & Castelló \\
\hline Comerços/1.000 hab. & 21,4 & 21,6 & 22,3 & 20,6 & 23,5 \\
Superfície m²/1.000 hab. & 2.433 & 2.663 & 2.701 & 2.588 & 2.858 \\
Hab./centre comercial & 84.926 & 83.011 & 76.666 & 74.057 & 94.991 \\
Equipaments & 550 & 64 & 24 & 34 & 6 \\
$\mathrm{~m}^{2} / 1.000$ hab. SBL & 335 & 388 & 368 & 427 & 279 \\
SBL m $^{2}$ & & 1.922 .874 & 675.465 & 1.085 .795 & 161.614 \\
\hline
\end{tabular}

SBL: superfície bruta llogable.

Font: PATECO. Elaboració pròpia.

les empreses unilocalitzades havien davallat fins al $84,5 \%$, i el de les petites cadenes (com les de mobles), fins al 85,2\%, mentre que les vendes de les grans cadenes havien augmentat fins al 106,2\% (PATECO, 2016).

A la Comunitat Valenciana el suport explícit i implícit de l'Administració als nous formats comercials es manifesta de múltiples maneres. En destaca la millora de la xarxa de transports, que, sense obeir de manera explícita les exigències dels centres comercials, n'afavoreix els patrons d'assentament (a Alacant, els accessos des de la xarxa d'autovies i autopistes al lloc triat per Ikea semblen fets a propòsit). També les ofertes dels ajuntaments, en competència entre municipis, per a captar aquesta inversió comuna entre ciutats com a estratègia per a definir nous pols de desenvolupament urbà (Whyatt, 2004), evitar l'evasió de la despesa i potenciar l'atractiu de la ciutat, que capta així clients atrets pel focus Ikea, però amb desplaçaments multipropòsit que afavoreixen el conjunt de la ciutat (Arentze et al., 2005). A Alacant també sembla que és el cas de l'existència d'ajudes institucionals per al desenvolupament de productes immobiliaris associats al centre comercial com una part de l'estratègia de negoci (González-Benito et al., 2005).

Més en concret, els establiments Ikea a la Comunitat Valenciana i a la Regió de Múrcia haurien desenvolupat una altra sèrie d'estratègies i de tàctiques comunes al comerç minorista especialitzat, com les d'adaptació a l'heterogeneïtat dels consumidors (Baker i altres, 2002), l'ampliació de la gamma de productes, l'extensió dels horaris d'obertura i la millora dels serveis oferts al client (Gutiérrez, 2014), l'ampliació dels espais destinats a l'oci dins de l'establiment mateix i la seua vinculació amb altres comerços especialitzats complementaris, com ara els del fabricant (entre aquests, amb Porcelanosa com a establiment també dotat de carisma), que afavoreixen la percepció subjectiva d'atracció, ja no únicament de l'establiment, sinó també de l'espai en què s'insereix (Wang, 2005).

En la síntesi que recull la taula 5 s'hi observa com la ràtio de metres quadrats per habitant de superfície bruta llogable en centres comercials sobrepassa la d'Espanya, especialment en la província de València. Pel que sembla, els nous hàbits de consum minorista ja estarien ben desenvolupats i l'estructura de la demanda animaria la penetració de nous formats comercials periferics. 


\section{Les estratègies de geomàrqueting d'Ikea a la Comunitat Valenciana}

La instal.lació d'Ikea ha afectat sensiblement el mercat del moble valencià, sector fabril de llarga tradició, innovador i exportador, que ha desenvolupat un destacat sistema productiu local concentrat a l'àrea metropolitana de València (comarca de l'Horta Sud), precisament on s'ha instal.lat el magatzem de València i que ha trobat l'oposició inicial de tot el potent sector: Associació Provincial d'Empresaris, Comerciants, Magatzemistes i Detallistes de Mobles (en castellà, FECOMVAC), i Federació Empresarial de la Fusta i el Moble (en castellà, FEVAMA) (Las Provincias, 4 de desembre de 2008). També s'ha vist afectat per aquesta circumstància el districte industrial del moble de Iecla (Regió de Múrcia: Associació Regional d'Empresaris de la Fusta —en castellà, AREMA—, amb el Centre Tecnològic del Moble i la Fusta), l'àrea de mercat natural del qual són les províncies d’Alacant i Múrcia.

Hem fet una anàlisi de geomàrqueting per a estudiar les àrees de mercat d'Ikea a la Comunitat Valenciana i a la Regió de Múrcia, encara que sense la profunditat dels estudis multicriteri, atès que els emplaçaments d'aquesta multinacional ja estan determinats ( $i$ en dos casos en funcionament). L'objectiu és conèixer les àrees de mercat ben servides - geodemanda- de Múrcia i València i predir la d'Alacant, atès que el veïnatge geogràfic de les tres ciutats podria suposar processos d'encavalcament, competència i minva potencial de clients - geocompetència- d'un comerç tan específic com Ikea, qüestions essencials per a determinar-ne la ubicació (Baviera et al., 2013). Es una circumstància que pel que sembla ha previst l'empresa mateix. De fet, el 2009 assenyalava que el mercat valencià quedaria cobert amb un total de cinc magatzems Ikea: un per a cada milió d'habitants (El Mundo, 4 de febrer de 2009).

Per estudiar la geodemanda s'ha partit del model maximize overall customer coverage ('maximitzar la cobertura global dels clients'; Bosque i Moreno, 2014) i, d'acord amb les distàncies recorregudes pels clients d'Ikea, s'han triat tres llindars temporals que han estat definits per les isòcrones de menys de 30 minuts, d'entre 30 i 60 minuts i de més de 60 minuts (figura 4). És un criteri que manté la configuració de les àrees comercials de la Comunitat Valenciana, articulada a l'entorn de la isòcrona de 30 minuts respecte de la ciutat central (PATECO, 2009). En qualsevol cas, els tres establiments Ikea analitzats concentren més del $50 \%$ de la seua clientela potencial per sota de la isòcrona de 15 minuts, la qual cosa es considera un factor de competitivitat molt destacat a la Comunitat Valenciana (Rovira, 2008).

Amb l'aplicació ArcGIS 10.1 s'ha calculat el centre de gravetat ponderat (amb els habitants) dels municipis per sota d'una hora de desplaçament i s'ha comprovat l'alta correlació entre el càlcul i el lloc triat per Ikea per a establir els seus tres centres comercials a València, Alacant i Múrcia. A partir de l'ajust per mínims quadrats de les distàncies, s'han establert tres cercles que definirien teòricament les distàncies mitjanes normals en els desplaçaments des de l'àrea d'influència fins a cadascun dels tres establiments Ikea, amb radis de 
Figura 4. Àrees d'influència comercial dels establiments Ikea a la Comunitat Valenciana i a la Regió de Múrcia, sobre base municipal

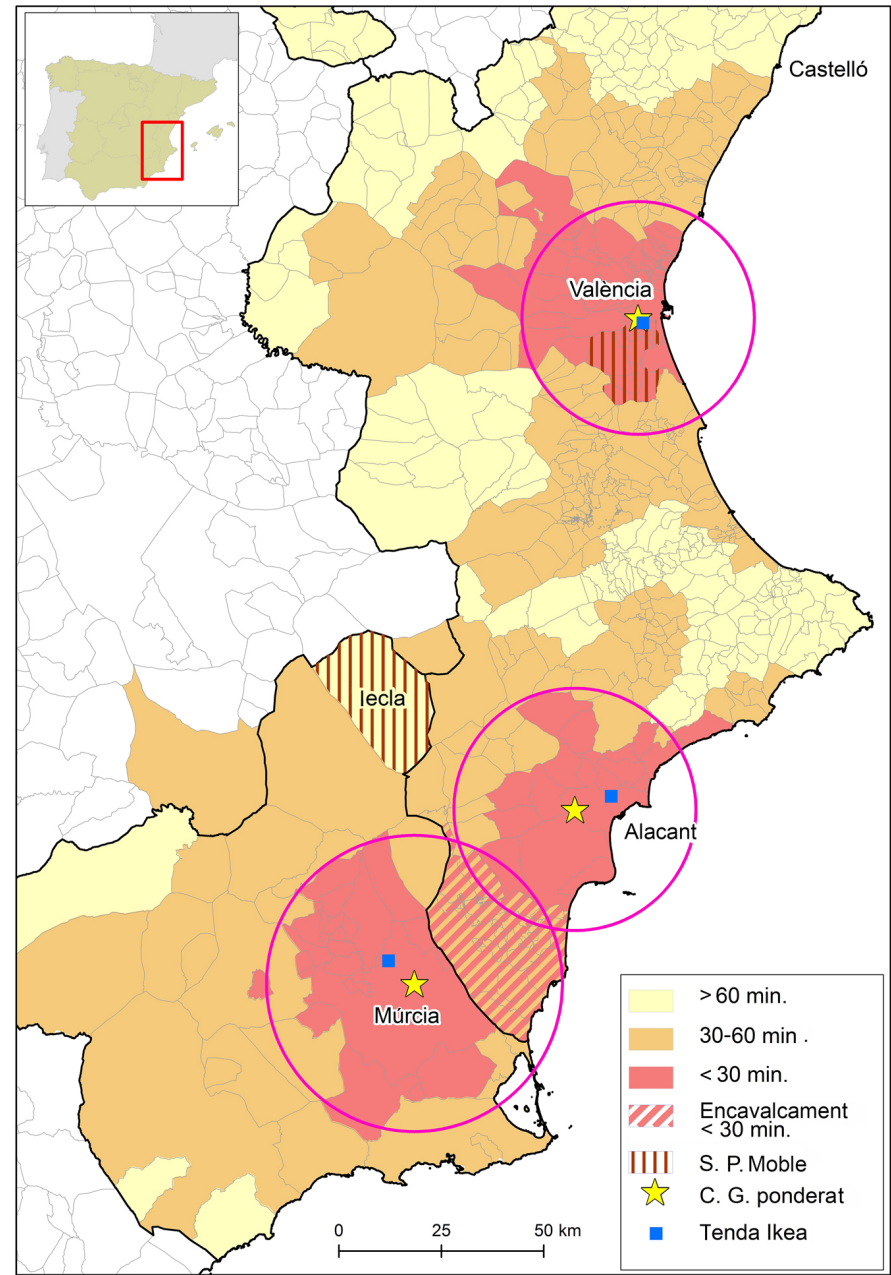

Font: Elaboració pròpia.

29,4 km a València, 29,5 km a Alacant i 36,1 km a Múrcia, segons la major o menor concentració de la població. S'ha comprovat com els cercles d'Alacant i Múrcia coincideixen en la comarca alacantina del Baix Segura, mentre que el de València se circumscriu pràcticament a l'entorn metropolità de la ciutat i deixa fora una bona part de la província homònima i la de Castelló (taula 6).

Són els consumidors els qui decideixen comprar en un centre comercial o en un altre d'acord amb multitud de criteris (Huff, 1963), entre els quals n'hi 
Taula 6. Establiments Ikea. Àrees d'influència i habitants segons isòcrones (any 2016)

\begin{tabular}{|c|c|c|c|c|c|c|}
\hline \multirow[b]{2}{*}{ Distància } & \multicolumn{2}{|c|}{ Múrcia } & \multicolumn{2}{|c|}{ València } & \multicolumn{2}{|c|}{ Alacant } \\
\hline & Província & $\begin{array}{c}\text { Altres } \\
\text { províncies (1) }\end{array}$ & Província & $\begin{array}{c}\text { Altres } \\
\text { províncies (2) }\end{array}$ & Província & $\begin{array}{c}\text { Altres } \\
\text { províncies (3) }\end{array}$ \\
\hline$<30$ minuts & 731.855 & - & 1.756 .054 & - & 856.480 & - \\
\hline De 30 a 60 minuts & 641.230 & 639.530 & 665.189 & 210.673 & 796.542 & 32.000 \\
\hline$>60$ minuts & 91.762 & - & 123.021 & - & 183.437 & - \\
\hline Total & 1.464 .847 & 639.530 & 2.544 .264 & 210.673 & 1.836 .459 & 32.000 \\
\hline
\end{tabular}

1. Alacant i Albacete; 2. Castelló; 3. Múrcia, València i Albacete.

Font: INE, elaboració pròpia.

ha de racionals, però també d'emocionals o de coneixement del context. A més, hi ha les utilitats o els aprofitaments —oferta comercial i lúdica complementària- que ofereix cada establiment. Potser per això el projecte Ikea d'Alacant (impulsat per agents locals) va tan acompanyat d'oferta complementària, per a poder optar amb majors garanties d'èxit enfront de la zona comercial ja desenvolupada en la periferia de Múrcia.

\section{El model econòmic aplicat al territori valencià}

Cal entendre que la instal.lació a Alacant suposa una clara estratègia d'ocupació d'un espai vacant abans que ho faça un altre possible competidor, encara que es minve considerablement l'àrea de mercat de l'Ikea de Múrcia.

Aquesta política expansiva encaixa en el model d'estratègia de desenvolupament proposat per la matriu d'Ansoff, o de vector de creixement (Ansoff, 1976), segons el qual la implantació successiva de magatzems d'Ikea en àrees de mercat cada vegada més reduïdes és possible perquè l'empresa manté una doble estratègia que es retroalimenta. D'una banda, les estratègies de penetració del mercat tenen per objectiu la captació de clients de la competència, però també la captació de nous clients, no consumidors actuals, mitjançant tàctiques de modificació d'hàbits de consum. D'aquesta manera, el mercat augmenta quantitativament i qualitativament. El producte venut és el de l'«experiència Ikea», que rau en la possibilitat de comprar i renovar els mobles de forma periòdica en un termini curt (gràcies a un preu baix) i activar el vincle emocional del client amb el moble fet per ell mateix (Inman et al., 2004).

Dahlvig (2012) assenyala que l'empresa compleix fil per randa les cinc forces d'assentament que defineix la matriu de Porter per a establir la cadena de valor d'una firma (Porter, 1989). Es tracta ara d'analitzar si es compleixen, en quina mesura i com s'han adaptat a la realitat de la Comunitat Valenciana. La primera fortalesa se centra en la captació de clients: sempre que s'estableix una nova companyia en un territori, augmenta la competència, s'abaixen els preus $i$ creixen les despeses en màrqueting (per a mantenir clients o per captar-ne de nous), circumstàncies que només una firma potent és capaç de suportar. L'abaixament dels preus impulsada pel model d'Ikea es donava, precisament, en 
Figura 5. Producció de mobiliari a la Comunitat Valenciana (unitats d'activitat econòmica i empleats) i anys d'obertura d'lkea

\section{Empleats}

UAE

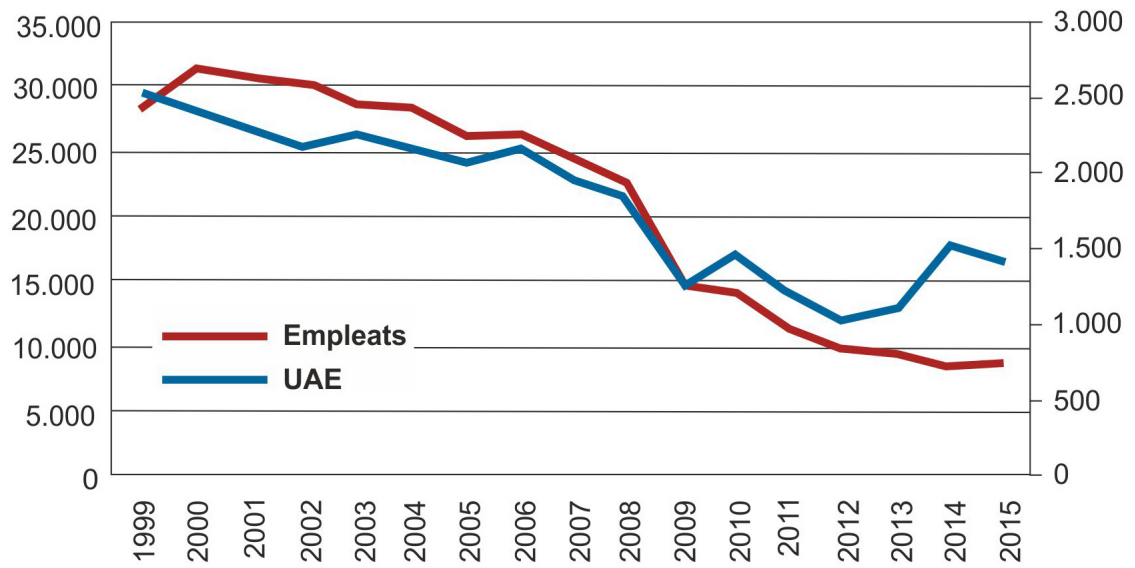

Font: CESSPCT. Elaboració pròpia.

uns moments de reestructuració del ram a la Comunitat Valenciana, afectada per una pèrdua constant de presència en el mercat estatal i mundial (figura 5).

Els greus efectes de la crisi han matisat l'impacte de l'obertura dels magatzems Ikea en la part fabril del sector. En tot cas, podria deduir-se que la seua influència s'ha sentit en la forta reestructuració del ram i en l'ajust als nous patrons de la demanda mitjançant dues fórmules de resiliència. D’una banda, la reducció de les plantilles (taula 7) i la cooperació horitzontal amb altres empreses complementàries i auxiliars: el 2014, el 67\% de les despeses d'explotació responien a treballs $\mathrm{i}$ a serveis contractats d'altres firmes complementàries i auxiliars (Conselleria d'Economia Sostenible, Sectors Productius, Comerç i Treball - CESSPCT, 2017). D’altra banda, les companyies més dinàmiques han procurat realitzar una concentració empresarial, mitjançant fusions i compres, per a aconseguir una grandària òptima. També s'ha engegat una altra de les estratègies avantatjoses d'Ikea, com és el de l'aproximació o integració vertical entre fabricació, logística i distribució comercial. Així, s'han promogut aliances entre proveïdors $\mathrm{i}$ distribuïdors del ram del moble. També alguns fabricants han optat per fer arribar els seus productes directament als clients (sense l'èxit d'Ikea), amb el propòsit d'evitar sobrecostos i d'acostar-se al client acurtant —o eliminant — els canals de distribució (AIDIMA, 2015).

La segona fortalesa té a veure amb l'existència de proveïdors. Els dos sistemes productius de la fusta i del moble (àrea metropolitana de València i Iecla) ofereixen un entorn molt apropiat, d'acord amb els mecanismes històrics de complementarietat desenvolupats entre empreses i l'estesa pràctica de la subcontractació (Ponce, 2003). En aquest sentit, una de les condicions 
Taula 7. Comunitat Valenciana. Evolució de la grandària de les empreses del moble

\begin{tabular}{|c|c|c|c|c|c|c|}
\hline \multirow[b]{2}{*}{ Estrat empleats } & \multicolumn{2}{|c|}{1980} & \multirow{2}{*}{$\begin{array}{c}2000 \\
\text { Empreses }\end{array}$} & \multirow{2}{*}{$\begin{array}{c}2005 \\
\text { Empreses }\end{array}$} & \multicolumn{2}{|c|}{2015} \\
\hline & Empreses & Empleats & & & Empreses & Empleats \\
\hline 0 a 9 & 1.330 & 4.592 & 1.366 & 1.264 & 1.232 & 2.976 \\
\hline 10 a 19 & 327 & 4.446 & 169 & 157 & 94 & 1.220 \\
\hline 20 a 49 & 301 & 9.420 & 98 & 94 & 65 & 1.808 \\
\hline 50 a 99 & 72 & 4.858 & 23 & 24 & 13 & 876 \\
\hline 100 i més & 18 & 3.384 & 9 & 4 & 9 & 1.781 \\
\hline Total & 2.048 & 26.700 & 1.665 & 1.543 & 1.413 & 8.661 \\
\hline
\end{tabular}

Font: INE, DIRCE i CESSPCT. Elaboració pròpia.

principals exigides pels fabricants del sistema productiu del moble de València, que el govern valencià mateix ha tingut en compte ${ }^{3}$, ha sigut que Ikea els contemple com a possibles proveïdors, condició que sembla que es va subscriure mitjançant acord el $2009^{4}$.

La tercera fortalesa consisteix a expulsar els competidors existents en el mercat valencià i evitar l'arribada d'uns altres de característiques similars. L'estratègia d'implantació progressiva (inclòs l'Ikea de Múrcia) compleix aquest objectiu d'ocupar-ne sòlidament el camp comercial. Per això, amb el propòsit de mantenir la competitivitat de les empreses del moble a la Comunitat Valenciana, l'Institut Tecnològic del Moble, Fusta, Embalatge i Afins (AIDIMA) ha engegat, des de 2009, l'Observatori de Tendències d'Hàbitat, amb el propòsit d'identificar les noves maneres de residir als habitatges i a les ciutats, els nous formats de família i com aquests canvis en l'hàbitat repercuteixen en la llar i en els seus components. L'objectiu és orientar la fabricació, com fa Ikea, cap a un disseny integral identificable, com a factor crític de competitivitat (AIDIMA, 2009). Malgrat això, sí que ha ocorregut l'expulsió d'alguns magatzems més febles de característiques similars, radicats anteriorment en el mercat valencià .

La quarta fortalesa es basa a dificultar l'aparició de nous productes que en facen rèplica. L'aparell publicitari, la integració vertical i l'economia d'escales d'Ikea converteix la companyia en líder del segment, ja que fixa els preus (sem-

3. Diari Las Provincias de 4 de desembre de 2008 (traducció): «El vicepresident del Consell, Vicente Rambla, va assegurar que en aquests moments la negociació sobre l'arribada d'Ikea a la Comunitat Valenciana se centra en les "condicions" perquè el sector del moble valencià no n'isca gaire perjudicat».

4. Diari Las Provincias de 3 de febrer de 2009 (traducció): «FEVAMA i FECOMVAC aconsegueixen un acord genèric amb Ikea».

5. Un exemple d'aquesta tendència en firmes dedicades al mobiliari modern i innovador de baix cost és Domus, una marca espanyola amb origen a Iecla, expandida per tot Espanya des de 2001 i amb magatzems a València i Alacant, actualment en procés de liquidació voluntària. Recuperat el 12 de maig de 2015, de <http://domus.sh/es/content/7-historia>. 
Taula 8. Matriu de Porter aplicada a Ikea a la Comunitat Valenciana

\begin{tabular}{lc}
\hline Fortaleses & Nivell \\
\hline 1. Capacitat de captació de clients & Alt \\
Concentració de nombre de clients & Alt \\
Possibilitat d'establir preus & Alt \\
Alt volum de compra & Alt \\
Dificultats perquè els clients puguen canviar d'empresa & Mitjà \\
Disponibilitat d'informació per part del comprador & Alt \\
\hline 2. Concentració de proveïdors & Alt \\
Concentració de nombre de proveïdors & Alt \\
Volum de compra & Mitjà \\
Quantitat de matèries primeres & Alt \\
Costos que implicaria canviar de matèries primeres & Alt \\
Nombre de productes substituts disponibles en el mercat & Mitjà \\
\hline 3. Expulsió de competidors & Alt \\
Economia d'escala & Alt \\
Diferències de producte quant a propietat & Alt \\
Valor de la marca & Alt \\
Requeriments de capital & Alt \\
Accés a la distribució & Alt \\
\hline 4. Barreres a productes replicadors & Alt \\
Propensió del comprador a canviar de marca (amenaça) & Baix \\
Preus dels productes alternatius (amenaça) & Baix \\
Facilitat de canvi del comprador (amenaça) & Baix \\
Nivell percebut de diferenciació de producte o de servei & Alt \\
Disponibilitat de substituts pròxims (amenaça) & Baix \\
\hline 5 Capacitat d'influir en els governs & Mitjà \\
Influència en mesures reguladores del sector & Baix \\
Influència en mesures reguladores urbanístiques & Mitjà/Alt \\
Capacitat de vincular-se amb institucions públiques & Mitjà \\
Capacitat de crear institucions finançades amb recursos públics & Baix \\
\hline
\end{tabular}

Font: elaboració pròpia.

pre a la baixa) ${ }^{6}$ i les qualitats (mes subjectes al disseny i a la moda que no pas a la durabilitat). Són unes altres empreses les que han d'ajustar els seus productes a aquelles directrius, cosa que de fet resulta molt difícil per a les que estan orientades a aquest segment dels sistemes productius del moble de València $\mathrm{i}$ Iecla: entre 1999 i 2014 , el nombre de firmes del ram va descendir de 2.533 a 1.515 a la Comunitat Valenciana i de 538 a 367 a la Regió de Múrcia.

6. Diari Cinco Días de 31 de maig de 2010 (traducció): «Preu. Des que l'empresa sueca es va implantar a Espanya, ja fa més de 13 anys, el descens acumulat en el preu dels seus productes ha sigut de més del 30\%, segons les dades facilitades per la firma mateix». Recuperat el 7 de juny de 2010, de <http://cincodias.com/cincodias/2010/05/31/econo$\mathrm{mia} / 1275552430 \_850215 . \mathrm{html}$. 
La cinquena fortalesa tracta sobre la capacitat d'influir entre els agents polítics per a afrontar amb avantatge la rivalitat enfront de possibles competidors. En la pràctica es concreta en el poder de decisió de la ubicació precisa de l'establiment: no on siga més convenient per a la ciutat i el seu sistema comercial, sinó en el lloc més avantatjós per a l'empresa, amb la possibilitat de desenvolupar propostes urbanístiques complementàries. A la Comunitat Valenciana aquesta decisió s'ha vist molt afectada pel marc legal (urbanístic i comercial), cosa que ha posat en relleu la importància d'aquesta barrera (que també va identificar Porter) a la penetració en un mercat.

\section{L'emplaçament en l'àrea metropolitana de València}

Per a l'elecció precisa de l'emplaçament a València es van barrejar diverses localitzacions estratègiques (figura 6), sempre al costat de les grans vies de

Figura 6. Intensitat de trànsit el 2016 en l'àrea metropolitana de València i emplaçaments que lkea va tenir en compte

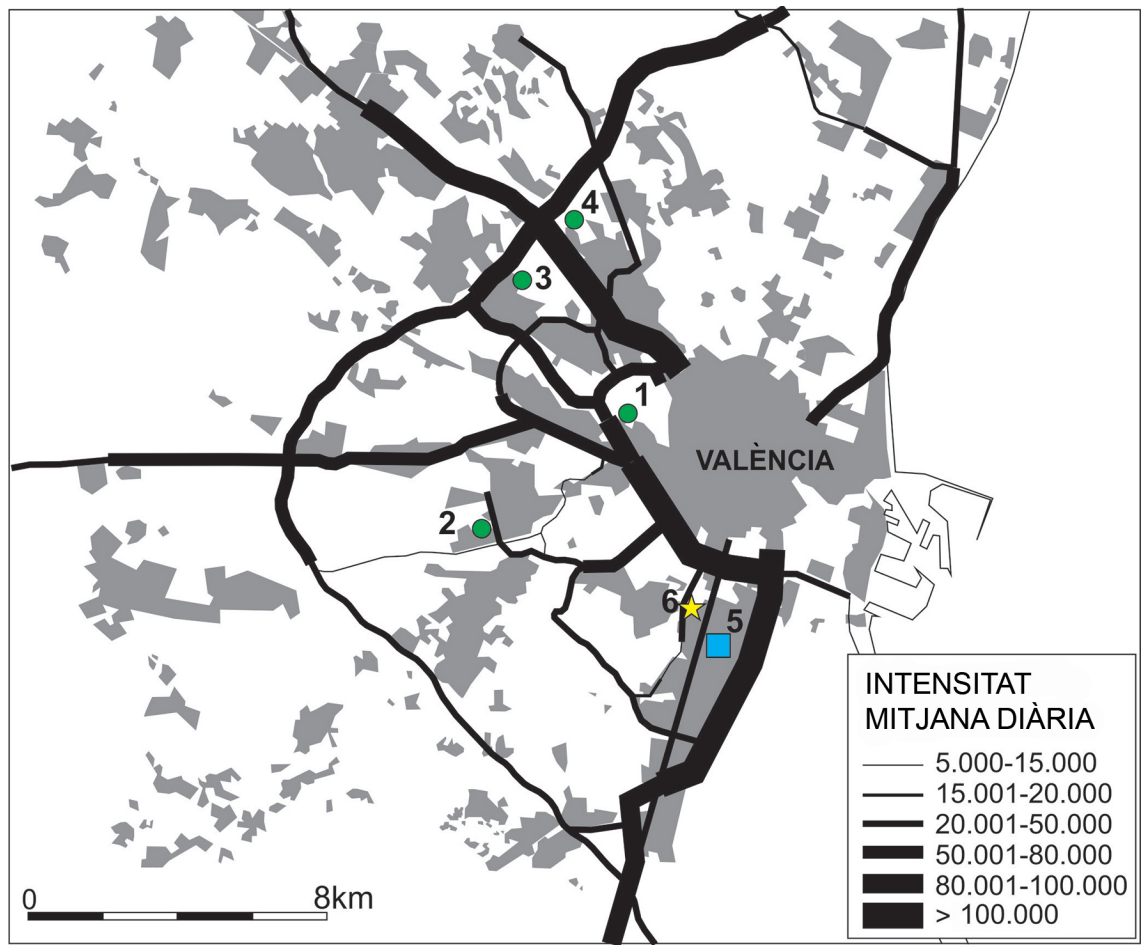

Llegenda: 1. Mislata; 2. Alaquàs; 3. Paterna; 4. Godella; 5. Alfafar; 6. Centre de gravetat ponderat calculat. En gris, sòl urbà consolidat.

Font: Ministeri de Foment. Elaboració pròpia. 
trànsit, vertebradores de l'àrea metropolitana i de la província mateix per davall de la isòcrona de 60 minuts (taula 6).

Mislata va ser la primera opció. És un municipi de superfície reduïda (210 ha), amb una situació privilegiada que suma, a les vies ràpides, la continuïtat urbana amb la ciutat de València. El seu pla general (PG) es va aprovar l'any 2003 (BOP València, núm. 26, 31 de gener de 2003) sense preveure grans equipaments al municipi, a causa de les dimensions reduïdes que mostra i d'una clara vocació residencial. Per això no hi havia prou sòl urbanitzable programat per a acollir les aproximadament 20 ha que demanava Ikea. Així, l'interès de l'empresa va decaure el 2005, malgrat que es van realitzar algunes modificacions puntuals del PG per a intentar captar aquesta inversió.

Alaquàs va ser l'alternativa següent. Es va redactar un nou PG, aprovat inicialment el 2008 (BOP València, núm. 108, 9 de juny de 2015), que permetria la instal.lació d'aquest equipament sobre 28 ha amb una gran accessibilitat $i$, alhora, amb l'edificabilitat més alta prevista per al sòl urbanitzable, la qual cosa hauria afavorit el desenvolupament de les promocions immobiliàries que ocasionalment acompanyen la multinacional sueca.

A Paterna, el PG de l'any 2000 experimentà diverses modificacions urbanístiques puntuals (2008, 2010 i 2011), l'Ajuntament posava en el mercat immobiliari 22 ha de sòl urbanitzable no programat, perquè fora Ikea mateix qui dissenyara el pla i l'ocupació del sòl d'acord amb els interessos de l'empresa. Però al mes de gener de 2010 es trencaren les negociacions.

Godella és un municipi en conurbació amb Paterna que va intentar captar la inversió arran de les dificultats que hi va haver en les negociacions amb el municipi veí. El seu PG, aprovat el 1990, se sotmetia el 2005 a una modificació puntual per a regular, entre altres aspectes, l'ordenança comercial i la complementarietat d'aquest ús amb el residencial (BOP, 15 de juny de 2006).

Finalment es va optar per Alfafar, municipi integrat en el sistema productiu local del moble i la fusta. El seu PG (BOPV, núm. 53, 3 de març de 1992) s'havia adaptat al terciari genèric: logística per a la fusta i el moble, comerç i oci de descongestió de València. El 2004 es modificà el PG per a rebaixar els condicionants a la implantació comercial. Es va constituir legalment l'Agrupació d'Interès Urbanístic (AIU) Alfafar Parc, que el 2006 sol-licitava al Govern valencià l'inici del concurs per a l'adjudicació, per gestió indirecta, d'un programa d'actuació integrada (PAI) per a desenvolupar urbanísticament 22,2 ha, classificades com a sòl urbanitzable no programat comercial, sobre un espai d'horta tradicional, al costat del nou eix traçat per la V-31. L'any 2006 Alfafar Parc incloïa la tenda Ikea com a reclam essencial per a una nova zona d'oci i comerç. Tanmateix, les desavinences entre promotors i la multinacional (i el joc negociador d'aquesta amb altres ajuntaments) van fer que el 2009 desapareguera la firma comercial del projecte.

$\mathrm{Al}$ final, les pressions de la multinacional farien efecte i en aquell any aconseguia un acord molt favorable amb l'AIU i l'Ajuntament d'Alfafar mateix, segons el qual Ikea rebutjava la construcció d'un macrocentre i se cenyia a l'ocupació de $45.000 \mathrm{~m}^{2}$ dins d'Alfafar Parc (figura 7). Amb aquesta fina- 
Figura 7. Ikea a Alfafar Parc. Les dotacions i els accessos genèrics per al parc comercial van ser decisius en l'elecció

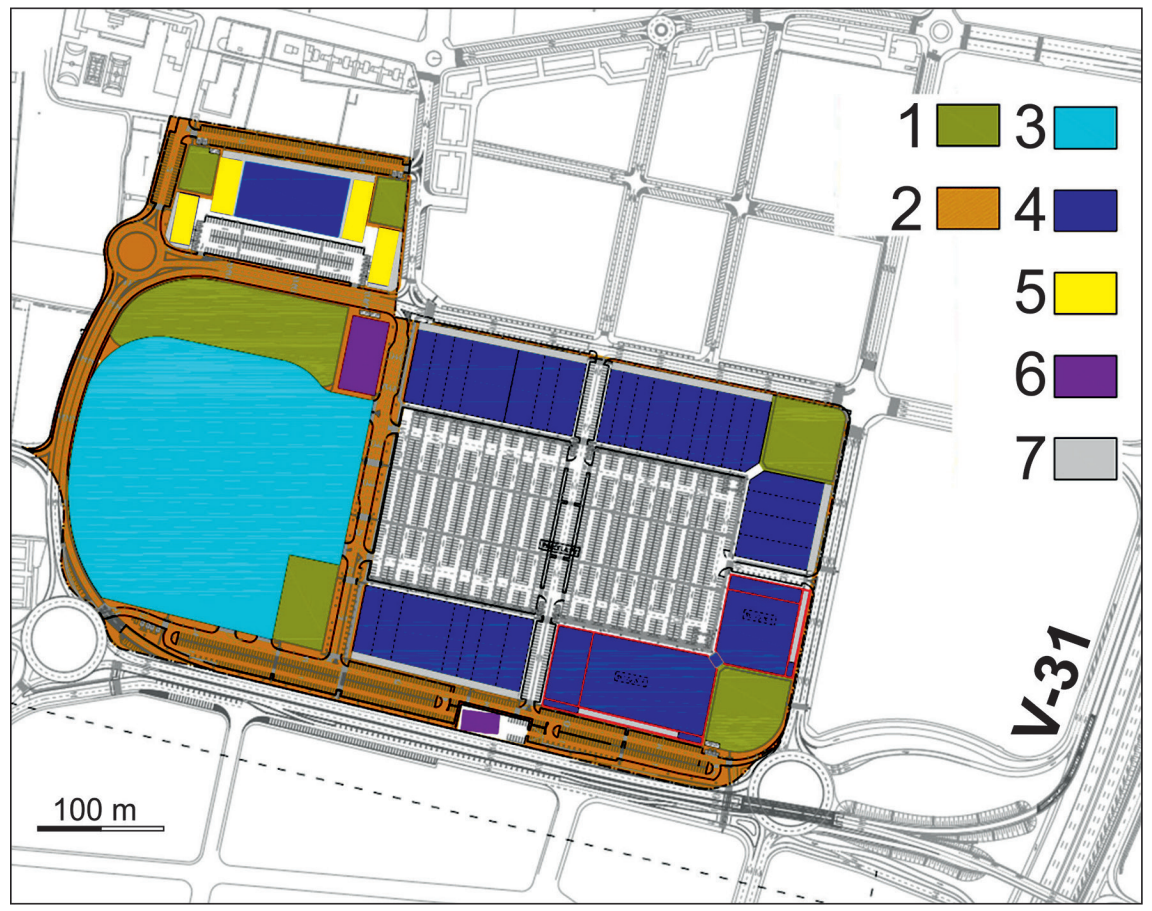

Llegenda: 1. Zona verda; 2. Sistema viari públic; 3. Comercial i parcel·la especial (Ikea); 4. Comercial i superfícies mitjanes; 5. Terciari; 6. Hostaler; 7. Àrees vinculades a les parcel-les edificables.

Font: Conselleria d’Habitatge, Obra Pública i Vertebració del Territori. Elaboració pròpia.

litat, l'Ajuntament mateix cedia gratuïtament a Ikea Ibèrica del 10\% de l'aprofitament urbanístic que li corresponia pel desenvolupament del pla parcial, i els membres de l'AIU venien a preu taxat mitjançant acord amb Ikea un altre 10\% del total del sòl útil resultant (Levante, 13 d'octubre de 2012). El 2014 obriria el magatzem, amb una modificació definitiva del PG el 2015.

Amb aquesta decisió, la capacitat d'influir en els agents polítics quedava matisada. Es evident que va fer efecte entre els responsables locals, disposats a modificar els seus plans generals per a captar la inversió, però no entre el Govern autonòmic, sens dubte amb una capacitat de negociació major. Així, l'empresa, en un emplaçament d'unes 5 ha, renunciava als desenvolupaments d'oci, comerç complementari i residencial que acompanyen algunes de les seues tendes. Alhora, mostrava una certa flexibilitat a pactar diversos acords empresarials amb fabricants del moble i la fusta del sistema productiu local.

És un emplaçament que coincideix quasi exactament amb el centre de gravetat ponderat calculat en aquest treball. Això suggereix la possibilitat següent: 
el fet que l'empresa haja tingut en compte uns altres emplaçaments, encara que possibles per la proximitat, podria tractar-se d'una estratègia elemental de negociació.

\section{Ikea com a subjecte passiu}

A Alacant, les expectatives d'Ikea s'han centrat en la zona de Rabassa (figura 8). És un indret amb unes condicions d'accessibilitat excel-lents, lleugerament separat del centre de gravetat ponderat (més allunyat de la concentració suburbana i amb pitjors accessos), de manera que l'empresa resulta afavorida per la cruïlla viària: una rotonda potent — amb passos elevats — construïda el 2007, en la qual desemboquen els eixos radials i les dues grans circumval-lacions del continu urbà a l'entorn d'Alacant i de la província homònima (com s'apuntava, sembla una infraestructura feta ad hoc per a afavorir el desenvolupament immobiliari proposat en aquest punt des de 2004, on després apareixeria l'interès d'Ikea).

Sobre el solar concret, l'avançament de la revisió del PG (que segueix sense aprovar-se) proposava un desenvolupament residencial d'unes 200 ha. El 2005,

Figura 8. Intensitat de trànsit el 2016 a l'entorn de la ciutat d'Alacant

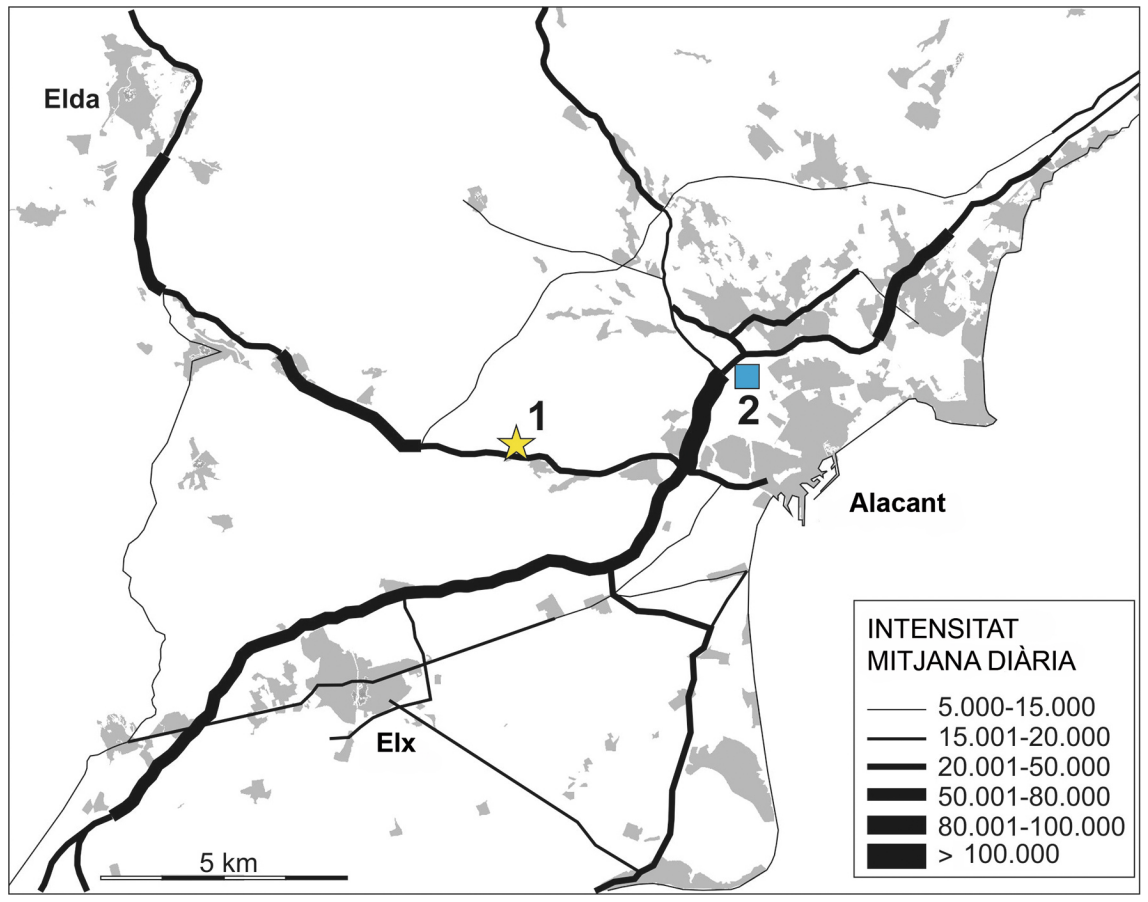

1. Centre de gravetat ponderat; 2. Ubicació prevista per a lkea. En gris, sòl urbà consolidat.

Font: Ministeri de Foment. Elaboració pròpia. 
a instància de l'empresa immobiliària propietària del sòl —VISOMED— es proposava ampliar l'actuació fins a 370 ha. Per aquesta divergència i d'altres sobre el model de ciutat, el 2007 es va canviar l'equip redactor de la revisió del PG. El 2009 es feia l'aprovació inicial del nou PG, que preveia l'ampliació proposada sobre el denominat Pla Rabassa. El Govern autonòmic hi donava el vistiplau, encara que reduint-ne l'edificabilitat de 17.700 a 13.503 habitatges (figura 9).

Entre els promotors i els governs municipal i autonòmic funcionava la sintonia, però aquesta avinença era percebuda per la ciutadania i l'oposició política com un clar procés especulatiu i, per mitjà d'un recurs contenciós administratiu, es va aconseguir paralitzar l'operació. El 2010 s'alçava la suspensió cautelar, i de llavors ençà hi ha hagut diversos litigis amb diferent signe resolutiu que n'han enterbolit la tramitació.

Els promotors, constrets per la crisi i amb els interessos afectats pels processos judicials, van decidir reduir la càrrega immobiliària a canvi de potenciar l'oferta comercial, d'oci i d'equipaments, a l'empara de les Mesures urgents d'impuls a la implantació d'actuacions territorials estratègiques, de 2011 (mecanisme ideat per a no estar entrebancats pel marc legal i donar resposta àgil a propostes de desenvolupament econòmic en temps

Figura 9. Pla Rabassa, 2004 i 2014

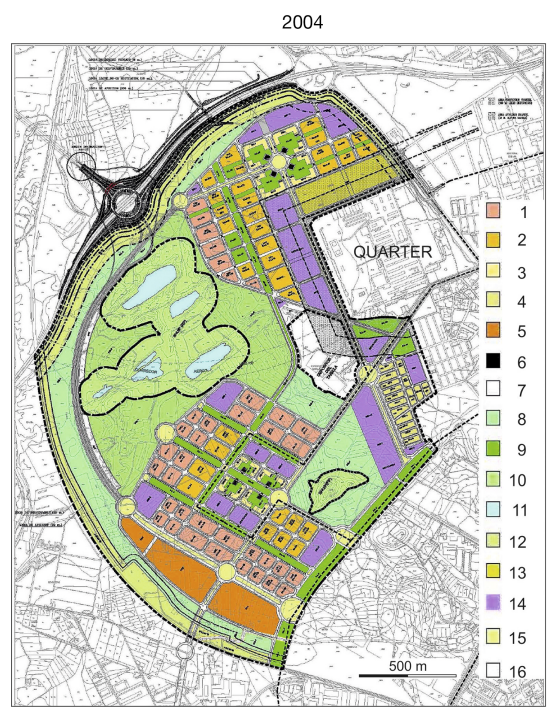

1 a 3. Zona residencial múltiple; 4. Habitatges unifamiliars; 5. Sector terciari comercial; 6 . Oficines; 7 . Parc urbà; 8 i 9 . Zona verda 10. Zona de protecció especial; 11. Estanys; 12. Parc de transports; 13. Dotacions esportives; 14 . Equipaments; 15 i 16 . Xarxa urbana.

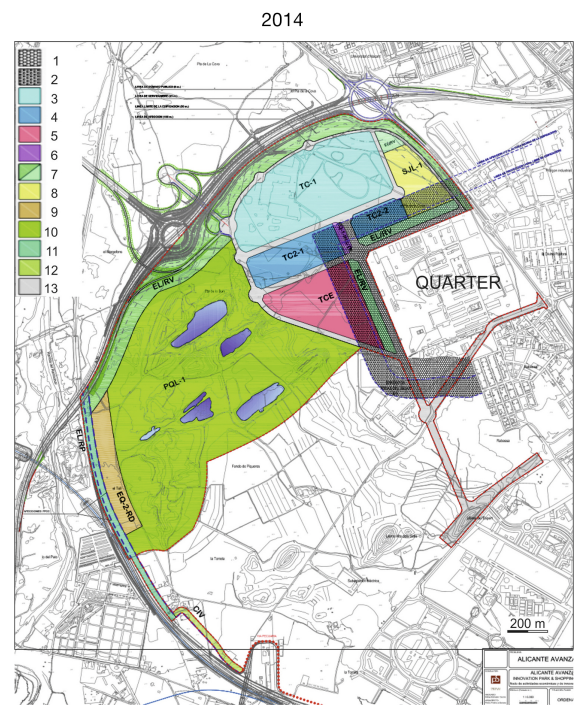

1. Àrea de protecció del quarter; 2. Àrea a què afecta el quarter; 3. Centre cívic terciari comercial ATE-Ikea; 4 . Zona terciària complementària; 5. Parc científic empresarial; 6. Transport públic; 7. Reserva viària i aparcament viari; 8 . Jardins; 9 . Zona esportiva i recreativa; 10. Parc públic metropolità; 11. Protecció del ferrocarril; 12. Corredor d'infraestructura verda; 13. Xarxa viària.

Font: AVANT, 2012. CVOPVT, 2014. 
de crisi). Així, el Pla Rabassa s'emparava en un ATE, cosa que preveia ja el magatzem d'Ikea.

Es donava una conjunció d'interessos entre els promotors locals i els estrategs de la firma sueca, cosa que es ratificava el 2010 per conveni amb VISOMED. Amb aquesta aliança, davant la magnitud del paquet de sòl, era possible que hi hagués un nou producte en forma de ciutat intel.ligent (smartcity), com la que Ikea proposa en l'Strand East de Londres ${ }^{7}$. Ací, l'oferta essencial són els habitatges, envoltats d'oficines, comerços - Ikea i uns altres de complementaris-, cafeteries, restaurants, cinemes i altres equipaments, entre els quals n'hi ha de tipus esportiu, zones verdes i un parc científic a Alacant (figura 9).

L'ATE s'aprovà el 2014, però, en vista de la contestació ciutadana per la manera com condicionaven el model de ciutat que havia conjuminat el procés de revisió del PG, la resposta del Govern municipal fou retirar el 2015 la tramitació del PG i mantenir la de l'ATE. El Pla Rabassa es reduïa a 230 ha, mentre que la zona comercial a l'entorn d'Ikea es concretava en un sostre de 30 ha (quan el pla comercial d'Alacant calculava les necessitats comercials de la ciutat en 6,5 ha de sostre per a l'horitzó de 2016).

Després del canvi de governs municipal i autonòmic en les eleccions de 2015 i dels revessos legals, el 2016, l'empresa local VISOMED desistia de la promoció immobiliària i, a partir d'aquest moment, era Ikea qui n'exercia les negociacions. Es proposava un nou parc comercial, d'oci i d'equipaments sobre unes 80 ha, mentre els governs local i autonòmic - interessats també en la instal-lació - plantejaven reduir el pla a 40 ha i desenvolupar-lo mitjançant una iniciativa pública "per a netejar la imatge del projecte».

Podria concloure's que la cinquena fortalesa de Porter sí que s'hi va exercir i que, de fet, va estar a punt de concretar-se amb l'aprovació de l'ATE el 2014, encara que de manera matisada. En aquest cas, el poder d'influència en els polítics l'exerciren els empresaris locals. Es comprova, com en el cas de València, la voluntat dels governs municipals d'afavorir la instal.lació de la firma sueca, pel fet de ser més o menys flexibles en la negociació.

\section{Conclusions}

Sembla que es pot comprovar que la implantació d'Ikea a la Comunitat Valenciana s'ajusta a estratègies generals de penetració i conquesta dels mercats locals desenvolupades pels nous formats comercials en territoris de demanda madurs, configurats per dilatades àrees suburbanes amb nous hàbits d'oci i consum. Les tècniques d'anàlisi de geodemanda han mostrat una gran coincidència amb els emplaçaments elegits. També es pot verificar que les tàctiques de localització - geomàrqueting — s'ajusten en gran mesura a la matriu d'Ansoff, i el desenvolupament d'estratègies de penetració en els mercats, a la matriu de Porter. La cinquena fortalesa de Porter sí que s'ha exercit (a punt

7. El model urbanístic d'Ikea. Recuperat el 26 de juny de 2016, de <http://blog.construmatica. $\mathrm{com} /$ strand-east-el-modelo-urbanistico-de-ikea/>. 
de concretar-se amb l'aprovació el 2014 de l'ATE a Alacant), bé que matisada per la contestació social. No obstant això, es comprova, tant a Alacant com a València, la voluntat dels governs municipals d'afavorir la instal-lació de la firma sueca d'una manera més o menys flexible des del punt de vista de la negociació. En tot cas, sembla acomplit l'objectiu de demostrar la recerca de la subordinació de les figures de planejament urbanístic al poderós sistema comercial.

Arribem així a l'objectiu central del treball: evidenciar l'enorme capacitat de maniobra de les grans empreses comercials quan fan front a dèbils plans d'ordenació urbana i reivindicar la integració de la funció comercial, per la seua potència, com a eina substancial en els plans generals d'ordenació urbana.

\section{Referències bibliogràfiques}

Aguirre de Cárcer Rojo, M. (2014). El caso de internacionalización de Ikea y su adaptación a las culturas locales. Madrid: U.P. Comillas, 59 p. Recuperat de <https:// repositorio.comillas.edu/xmlui/bitstream/handle/11531/461/TFG000275. pdf? sequence $=1>$.

AIDIMA (2009). Nuevas formas de habitar: Monográfico OTH/1. Recuperat de <http:// www.aidima.es/@aidimainforma/publicacion-nuevasformasdehabitar>.

- (2015). Smart city trends: Tendencias en las ciudades inteligentes y oportunidades para los sectores del hábitat. Recuperat de <https://es.slideshare.net/observatorioth/smart-city-trends-tendencias-en-las-ciudades-inteligentes-y-oportunidades-para-los-sectores-del-hbitat>.

Alcaide, J.C.; Calero, R. i Hernández, R. (2012). Geomarketing: Marketing territorial para vender y fidelizar más. Madrid: ESIC, 219 p.

Allaway, A.; Black, W.; Richard, M. i Mason, J. (1992). «Evolution of a Retail Market Area: An Event-History Model of Spatial Diffusion». Economic Geography, 70 (1), 23-40.

Ansoff, H.I. (1976). La estrategia de la empresa. Pamplona: EUNSA, 247 p.

Arentze, T.; Oppewall, H. i Timmermans, H. (2005). «A Multipurpose Shopping Trip Model to Assess Retail Agglomeration Effects». Journal of Marketing Research, $17,109-115$.

Baker, S.; Stephens, D. i Hill, R. (2002). «How Can Retailers Enhance Accessibility: Giving Consumers with Visual Impairments a Voice in the Marketplace». Journal of Retailing and Consumer Services, 9 (4), 227-239.

Baviera, A.; Buttrago, J. i Rodríguez, J.E. (2013). «Un modelo de geomarketing para la localización de supermercados: Diseño y aplicación práctica». Documentos de Trabajo de la Cátedra Fundación Ramón Areces de Distribución Comercial (DOCFRADIS), 1, 1-27.

BERTRAN, J. (2011). «Cap a una gestió integrada de les polítiques sectorials al territori de baixa densitat». A: Estratègies vers la ciutat de baixa densitat: De la contenció a la gestió. Barcelona. Diputació de Barcelona, 264-317.

BoIra, J.V. (2000). «Urbanismo y actividad comercial en el Área Metropolitana de Valencia». Las grandes superficies comerciales del Area Metropolitana de Valencia. València: Universitat de València, 81-94.

Bosque Sendra, J. i Moreno Jiménez, A. (coord.) (20I4). Sistemas de Información Geográfica y Localización Óptima de Instalaciones y Equipamientos. Madrid: RA-MA, 414 p. 
Burriel, E. (2009a). «La planificación territorial en la Comunidad Valenciana (19852009)». Scripta Nova, XIII (306), 1 de desembre de 2009. Universitat de Barcelona. Recuperat de <http://www.ub.edu/geocrit/sn/sn-306.htm>.

- (2009b). «La Unión Europea y el urbanismo valenciano». Boletín de la Asociación de Geógrafos Españoles, 49, 5-24.

Burt, S.; Johansson, U. i Thelander, Å. (2011). «Standardized marketing strategies in retailing?: IKEA's marketing strategies in Sweden, the UK and China». Journal of Retailing and Consumer Services, 18, 183-193.

Cerdá, L.M. (2007). Caracterización de los factores de éxito de los centros comerciales abiertos desde la perspectiva de los comerciantes: Un estudio empirico en el municipio de Getafe. Madrid: UAM, 422 p. Recuperat el 12 de desembre de 2017, de <https:// repositorio.uam.es/bitstream/handle/10486/2291/1599_cerda_suarez_luis_manuel.pdf? sequence $=1 \&$ is Allowed $=y>$.

- (2014). «La realidad aumentada como herramienta de innovación en marketing: El catálogo de Ikea redecora tu casa». Casos, 2, 105-112.

Cliguet, G.; Perrigot, R. i Gilsaura, I. (2006). «El futuro de los hipermercados en España: ¿Qué se puede aprender de la experiencia francesa?». Información Comercial Española, 11 (3), 35-52.

Conselleria d'Economia Sostenible, Sectors Productius, Comerç i Treball CESSEPCT (20I7). El comerç valencià en xifres. Recuperat de: <http://www.indi. gva.es/va/web/comercio/estudios-y-paper-works>

Cruz Roche, I. (coord.) (2002). «El impacto del supermercado sobre el comercio urbano». Cuadernos de Asedas, 3, 79 p.

Dahlvig, A. (2012). Cómo hacemos las cosas en Ikea. Barcelona: Gestión 2000, 184 p.

Desse, R. (2009). "La géographie du commerce au risque de l'urbanisme comercial». Bulletin de la Société Géographique de Liège, 52, 97-100.

- (2010). «Les territoires emboîtés de Wal-Mart». Bulletin de la Société Géographique de Liège, 55, 29-42.

Desse, R.; MAdry, P. i WAYEns, B. (2016). «Acteurs et opérateurs du commerce actors and operators of retailing». Bulletin de la Société Géographique de Liège, 66, 45-50.

Dugot, P. i Pouzenc, M. (dir.) (2010). Territoires du commerce et développement durable. París: L'Harmattan, 241 p.

Elizagarate, V. (2005). «El comercio y la regeneración urbana de la ciudad: Una estrategia integral de marketing de ciudades». Distribución y Consumo, 15 (84), 40-49.

Espinosa, A. (2007). El comercio como herramienta estructuradora del territorio: El caso de las ciudades alicantinas. Alacant: Universidad d'Alacant. Tesi doctoral, 530 p.

González-Benito, O.; Muñoz-Gallego, P.A. i Kopalle, P.K. (2005). «Asymetric Competition in Retail Store Formats: Evaluating Inter- and Intra-Format Spatial Effects». Journal of Retailing, 8 (1), 65-79.

Gutiérrez, J.L. (2014). Metodología integral para la determinación de una gran superficie comercial. Aplicación empirica en Gran Canaria. Gran Canarias: Dpto. Economía y Dirección de empresa. Universidad de las Palmas de Gran Canaria, 337 p.

Hermosilla, J. (2000). «Caracterización de los clientes de hipermercados del Área Metropolitana de Valencia». A: Las grandes superficies comerciales del Área Metropolitana de Valencia. València: Universitat de València, 63-80.

Huff, D.L. (1963). «A Probabilistic Analysis of Consumer Spatial Behavior». A: Decker, William S. de. Emerging Concepts in Marketing. Chicago: American Marketing Association, 443-461. 
InDOvinA, F. (2006). "Transformaciones de la ciudad y el territorio a principios del siglo XXI: El archipiélago metropolitano». La ciudad fragmentada: Nuevas formas de hábitat. Alacant: Universitat d'Alacant, 13-42.

Inman, J.; Shankar, V. i Ferraro, R. (2004). "The Roles of Channel-Category Associations and Geodemographics in Channel Patronage». Journal of Marketing, 68, 51-71.

Jones, K. i Simmons, J. (1990). The Retail Environment. Londres: Routledge.

Jonsson, A. i Foss, N. (2011). «International expansion through flexible replication: Learning from the internationalization experience of IKEA». Journal of International Business Studies, 42, 1079-1102.

López de Lucio, R. (2002). «La vitalidad del espacio público urbano en riesgo». Distribución y Consumo, noviembre-diciembre, 25-41.

Ministeri de Foment (2000). Atlas estadístico de las áreas urbanas de España. Madrid: Ministeri de Foment, 173 p.

- (2006). Atlas estadístico de las áreas urbanas de España. Madrid: Ministeri de Foment, $326 \mathrm{p}$.

- (2017). Áreas urbanas de España. Madrid: Ministeri de Foment, 34 p.

Muñoz, F. (coord.) (2011). Estratègies vers la ciutat de baixa densitat: De la contenció a la gestió. Barcelona: Diputació de Barcelona, 496 p.

NeL.LO, O. (1996). «Els confins de la ciutat sense confins: Estructura urbana i límits administratius de la ciutat difusa». A: La ciutat difusa i les periferies: Experiències de planificació i gestió. Girona: Universitat de Girona, 55-71.

PATECO (2009). Atlas Sociocomercial de la Comunitat Valenciana 2009. València: Generalitat Valenciana. Cambres de Comerç de la Comunitat Valenciana, cap. 4, $55 \mathrm{p}$.

- (diversos anys). Informe Anual de la Distribución Comercial Minorista en la Comunidad Valenciana. València: Generalitat Valenciana. Cambres de Comerç de la Comunitat Valenciana. Recuperat de <http://www.pateco.es/informes/informe. php?idInforme $=34$ \&izq $=-$ Analisis $>$.

Ponce, G. (2003). Reestructuración y territorio en los sistemas productivos industriales valencianos. Alacant: Universitat d'Alacant, 378 p.

- (2005). «De la taylorización a la vertebración del territorio valenciano». Ciudady Territorio, XXXVII (143), 105-124.

- (2006). "La fragmentación de la forma urbana en la Comunidad Valenciana». A: La ciudad fragmentada: Nuevas formas de hábitat. Alacant: Universitat d'Alacant, 89-130.

- (2013). «Estrategias de metropolización de la ciudad de Valencia en la etapa autonómica: La centralidad cuestionada en el modelo Postchristaller de ordenación del territorio». Boletín de la Asociación de Geógrafos Españoles, 62, 147-172.

- (2014). «El comercio en las estrategias de vertebración territorial de la comunidad valenciana». Estudios Geográficos, 276, 347-372.

Porter, M. (1989). Ventaja competitiva. Mèxic: Continental, 556 p.

Roger, M.; Grol, P. i Schoch, C. (1998). IKEA: Culture as Competitive Advantage. The European Case Clearing House: Case-Reference núm. 398-173-1, 40 p.

Rogers, E.N.; Sert, J.L. i Tyrwhitt, J. (1955). El corazón de la ciudad: Por una vida más humana de la humanidad. Barcelona: Hoepli, 183 p.

Rovira, A. (dir.) (2008). Medición de los factores de atractividad comercial de un municipio: El caso de la Comunitat Valenciana. València: Cambres i Generalitat Valenciana, $63 \mathrm{p}$. 
Salom, J. (2011). «Procesos territoriales y transformaciones recientes del sistema urbano Valenciano». Scripta Nova, XV (356). Recuperat de <http://www.ub.edu/ geocrit/sn/sn-356.htm>.

Salom, J. i Albertos, J.M. (2014). «Delimitación y caracterización de los nuevos espacios urbanos valencianos». Boletín de la AGE, 64, 127-150.

Salom, J. i Casado, J.M. (2007). "Movilidad cotidiana y mercados locales de trabajo en la Comunidad Valenciana, 1991-2001». Boletín de la AGE, 44, 5-38.

Torekull, B. (2008). La historia de IKEA. Madrid: La Esfera de los Libros, 395 p.

VAHÍ, A. i FERIA, J.M. (2007). «Estructuras urbanas y grandes formatos comerciales: El ejemplo de las áreas metropolitanas andaluzas». Eria, 72, 35-54.

WANG, Q. (2005). Economies of scale in Shopping Centre Industry. Estocolm: Division of Building and Real Estate Economics. Department of Infrastructure. Royal Institute of Technology.

Whyатт, G. (2004). «Town centre management: How theory informs a strategic approach». International Journal of Retail and Distribution Management, 32 (7), 346-353. 